\title{
Trichomonas vaginalis interactions with fibronectin and laminin
}

\author{
Marie-Laure Crouch and John F. Alderete
}

Department of

Microbiology, The

University of Texas Health

Science Center, 7703 Floyd

Curl Drive, San Antonio,

TX 78284-7758, USA
Author for correspondence: John F. Alderete. Tel: +1 210567 3940. Fax: +1 2105676612. e-mail: ALDERETE@UTHSCSA.EDU

The sexually transmitted protozoan Trichomonas vaginalis cytoadheres to vaginal epithelial cells and causes contact-dependent cytotoxicity which, when combined with the normal exfoliation process, leads to erosion of the epithelium, which may allow trichomonads into extracellular matrix and basement membrane sites. Therefore, the association of $T$. vaginalis with immobilized fibronectin (FN) and laminin (LM) on cover-slips was examined. Binding of live parasites to coated cover-slips was time- and parasite-densitydependent. Coincubation with an inhibitor of trichomonad cysteine proteinases resulted in an increased attachment of parasites to FN but had no effect on binding to $\mathrm{LM}$, denoting that protease activity influenced optimal FN associations. Further, $20 \mathrm{~h}$ mid-exponential phase trichomonads placed in fresh culture medium for $3 \mathrm{~h}$ gave higher levels of binding to FN, suggesting that changes during growth in vitro to $T$. vaginalis organisms affect maximal levels of binding to FN. Extended incubation with substrates diminished the capacity of parasites to bind FN and LM. Treatment of live organisms with periodate reduced binding to LM but not FN, suggesting a role for carbohydrates. In addition, trypsinization of live parasites decreased numbers bound to both substrates. Placement of trypsinized parasites in medium for $\mathbf{2} \mathbf{h}$ fully regenerated binding to FN but not LM. Incubation of trypsinized parasites with cycloheximide abrogated regeneration of attachment to FN, affirming a role for synthesized surface proteins in FN binding. Importantly, the $T$. vaginalis adhesin proteins that mediate cytoadherence, and iron, a factor that regulates adhesin synthesis, were not involved in FN and LM recognition. These results suggest a role for surface proteins and carbohydrates in trichomonal associations with FN and LM, respectively.

Keywords: colonization, fibronectin, laminin, pathogenesis, Trichomonas vaginalis

\section{INTRODUCTION}

Trichomonas vaginalis is a flagellated protozoan that causes the most prevalent non-viral sexually transmitted disease (STD) worldwide (World Health Organization, 1995). Trichomonosis is associated with significant morbidity for women, with vaginitis symptoms ranging from mild to severe inflammation, foul-smelling discharge, and severe irritation and discomfort (WolnerHanssen et al., 1989; Krieger et al., 1990; Soper et al., 1990). Infection by the parasite can have significant

Abbreviations: $B M$, basement membrane; $E C M$, extracellular matrix; FN, fibronectin; LM, laminin; TLCK, $N \alpha$-p-tosyl-L-lysine chloromethyl ketone; VECs, vaginal epithelial cells. health consequences for women, including increased risk for adverse pregnancy outcome (Hardy et al., 1984; Minkoff et al., 1984; Cotch et al., 1991; Read \& Klebanoff, 1993), HIV seroconversion (Wasserheit, 1992; Laga et al., 1993) and cervical cancer (Zhang \& Begg, 1994).

The vaginal wall consists of a stratified squamous outer epithelium and the underlying connective tissue. The hormones of the menstrual cycle, particularly oestrogen and progesterone, control the growth and differentiation of epithelial cells and ultimately lead to the terminal differentiation and exfoliation of vaginal epithelial cells (VECs). Maintaining and supporting the epithelium is a network of macromolecules comprising the extracellular matrix (ECM) and the basement membrane (BM), such as fibronectin (FN) and laminin (LM). 
As with other STD-causing pathogens, persistence within the urogenital tract by $T$. vaginalis would predictably require specific binding of the parasite to host structures. As such, these organisms adhere to VECs via surface adhesins (Alderete \& Garza, 1985, 1988; Alderete et al., 1988; Arroyo \& Alderete, 1989; Arroyo et al., 1992, 1995). However, exfoliation of VECs from the vaginal epithelium in addition to trichomonal cysteine-proteinase-mediated cytotoxicity (Alderete \& Pearlman, 1984) point towards parasites possibly residing at sites below the epithelial surface. This possibility may help explain the non-self-limiting nature of trichomonosis.

This report supports the existence of another mechanism by which $T$. vaginalis colonizes host tissues during trichomonosis. We hypothesized that persistence of parasites in the vagina may be due to the interaction of T. vaginalis with FN and LM. Early studies by us demonstrated the interaction of plasma proteins, including FN, with the T. vaginalis surface (Peterson \& Alderete, 1982, 1984a). In addition, parasite attachment to LM has been reported (Casta e Silva Filho et al., 1988; Benchimol et al., 1990). That LM does not reside on the surface of VECs (unpublished observations) suggests that specific parasite binding to FN may contribute to host parasitism. In this report, we demonstrate that $T$. vaginalis interacts with both $\mathrm{FN}$ and LM and that these associations are mediated by different mechanisms and surface sites from the previously identified adhesins (Arroyo et al., 1992). The relevance of these findings with regard to pathogenesis of trichomonosis is discussed.

\section{METHODS}

Culture and growth of $\boldsymbol{T}$. vaginalis. Fresh clinical isolates of $T$. vaginalis were axenized and passaged daily in normal medium of trypticase/yeast extract/maltose (TYM) supplemented with $5 \%$ heat-inactivated horse serum (Diamond, 1957; Peterson \& Alderete, 1982, 1984b). All isolates except for SA94-175 have been previously used by us in a variety of assays that display virulence properties, such as that involving the adhesins and cytoadherence (Arroyo et al., 1992, 1995) and expression of cysteine proteinases that degrade ECM/BM proteins (Provenzano \& Alderete, 1995; Provenzano et al., 1997). The isolates were not passaged in batch culture longer than 1 month, since long-term-grown trichomonads show decreased expression of some virulence properties (Lehker et al., 1991). High- and low-iron-grown trichomonads were cultivated in TYM-serum medium containing $50 \mu \mathrm{M} 2,2-$ dipyridyl (2,2-DP) for $24 \mathrm{~h}$ at $37^{\circ} \mathrm{C}$ starting with $10^{5}$ parasites $\mathrm{ml}^{-1}$ (Lehker et al., 1991). Organisms were centrifuged at $670 \mathrm{~g}$ and suspended in TYM-serum containing $75 \mu \mathrm{M} 2$ 2,2-DP for incubation for an additional $24 \mathrm{~h}$. These low-iron parasites were then harvested by centrifugation at $670 \mathrm{~g}$, seeded into individual flasks of medium supplemented with either $75 \mu \mathrm{M}$ 2,2-DP (low iron) or $250 \mu \mathrm{M}$ ferrous ammonium sulfate (high iron), and cultivated for $20 \mathrm{~h}$. Final cultures were processed as described below for the binding assay.

ECM components and coating of cover-slips. FN was purified from human plasma, obtained from the UTHSCSA hospital blood bank, by gelatin-Sepharose affinity chromatography according to the manufacturer's instructions (Pharmacia
Biotech). Briefly, human plasma was diluted 1:1 (v/v) in PBS prior to chromatography. Purified FN, at concentrations of $0 \cdot 5-1 \mathrm{mg} \mathrm{ml}^{-1}$, was dialysed for $48 \mathrm{~h}$ with three changes of PBS. Protein concentration was determined using bicinchoninic acid (BCA; Pierce Chemical). Entactin-free mouse LM was purchased from Collaborative Research (Becton Dickenson Labs). Cover-slips (12 mm diam.; Bellco Glass) were coated with $1 \mu \mathrm{g}$ FN or LM by spreading a $100 \mu$ l volume of the protein solution in PBS over the entire surface, as before (Peterson et al., 1983; Thomas et al., 1985). Cover-slips were then air-dried overnight at room temperature and washed by immersion in PBS before placing individual cover-slips in 24well plates. The uniform coating of cover-slips with each protein was confirmed by indirect immunofluorescence using specific antisera to each protein.

Parasite-binding assay. Parasites at $10^{5} \mathrm{ml}^{-1}$ were grown in normal medium containing $5-10 \mathrm{mCi}\left[{ }^{3} \mathrm{H}\right]$ thymidine $\mathrm{ml}^{-1}$ (185 MBq; Dupont, NEN Research Products). Efficient radiolabelling of parasites and the extent of radiolabel for each density of parasites used (specific activity) was monitored throughout, as before (Alderete \& Pearlman, 1984; Alderete \& Garza, 1985, 1988; Arroyo et al., 1992).

Trichomonads used in all binding assays were from the midexponential phase of growth $(\sim 20 \mathrm{~h})$ at $10^{6} \mathrm{ml}^{-1}$ (Peterson $\&$ Alderete, 1982). Except for the experiment presented in Fig. 2, radiolabelled parasites were then centrifuged and suspended in the same volume of medium without radioisotope for an additional $2 \mathrm{~h}$ at $37^{\circ} \mathrm{C}$ before use in binding assays. Trichomonads were then harvested and washed twice in minimal binding (MB) buffer (120 mM NaCl, $1.3 \mathrm{mM} \mathrm{KCl,} 0.9 \mathrm{mM}$ $\mathrm{NaH}_{2} \mathrm{PO}_{4}, 5 \cdot 5 \mathrm{mM}$ glucose and $\left.26 \mathrm{mM} \mathrm{NaHCO}_{3}, \mathrm{pH} 5 \cdot 0\right)$ by centrifuging at $670 \mathrm{~g}$ for $5 \mathrm{~min}$. Parasites were enumerated using a Neubauer haemocytometer (Alderete \& Pearlman, 1984; Alderete \& Garza, 1985; Peterson \& Alderete, 1982). Different numbers of organisms from $5 \times 10^{5}$ to $5 \times 10^{6}$ parasites in $1 \mathrm{ml} \mathrm{MB}$ buffer supplemented with $400 \mu \mathrm{M} \mathrm{N} \alpha-p$ tosyl-L-lysine chloromethyl ketone (TLCK; Sigma) were added to individual wells containing the protein-coated coverslips. These were incubated for $30 \mathrm{~min}$ at $37^{\circ} \mathrm{C}$ or as stated for each experiment. Cover-slips were washed by immersing several times in $37^{\circ} \mathrm{C}$ pre-warmed MB buffer. Bound radioactivity remaining on the cover-slips was measured by scintillation spectroscopy. The number of c.p.m. on coverslips reflected the number of parasites bound to FN or LM and was confirmed by light microscopy and enumeration of organisms in individual fields.

Two types of experiments were performed to demonstrate that trichomonads degrade $\mathrm{FN}$ immobilized on cover-slips. In one case, $30 \mu \mathrm{g}$ FN was coated onto the cover-slips and interacted with $3 \times 10^{6}$ organisms suspended in $400 \mu \mathrm{l}$ of the normal, complex TYM medium without serum. Wells were incubated at $37^{\circ} \mathrm{C}$ prior to collection of samples at the indicated time points. The samples were then processed as described below. Cover-slips were also coated with $10 \mu \mathrm{g} \mathrm{FN}$ and incubated with $10^{6}$ parasites per $\mathrm{ml} \mathrm{MB}$ buffer with or without TLCK added to each well. At different time points, supernatant was collected and centrifuged at $13000 \mathrm{~g}$ for removal of organisms. The trichomonads and supernatant were prepared for SDS-PAGE as described below.

Periodate and trypsin treatment of live trichomonads. Washed, pelleted radiolabelled parasites $\left(2 \times 10^{7}\right)$ were suspended in $10 \mathrm{ml} 1 \mathrm{mM}$ periodate prepared in PBS, as before (Alderete \& Garza, 1985), under conditions that do not adversely affect trichomonal motility and viability. Trichomonads were then incubated on ice for $30 \mathrm{~min}$ before washing 
twice in PBS prior to suspending in MB buffer for use in the binding assay, as described above. In a competition assay, the $\mathrm{MB}$ buffer was supplemented with $250 \mathrm{mM}$ maltose, glucose, sucrose or $\mathrm{N}$-acetylgalactosamine (Alderete \& Garza, 1985; Warton \& Honigberg, 1980, 1983). Trichomonads were suspended in the modified $\mathrm{MB}$ immediately prior to incubation with coated cover-slips at $37^{\circ} \mathrm{C}$ for $30 \mathrm{~min}$. MB buffer without sugars was used as a control.

Prior to protease treatment, $2 \times 10^{7}$ washed radiolabelled organisms from batch culture were incubated for an additional $2 \mathrm{~h}$ in fresh TYM-serum. Parasites were pelleted by centrifugation at $670 \mathrm{~g}$, suspended in $10 \mathrm{ml} \mathrm{MB}$ buffer containing $30 \mathrm{mg}$ trypsin (Sigma) and incubated for $30 \mathrm{~min}$ at $37^{\circ} \mathrm{C}$. The reaction was then terminated by the addition of equal amounts of trypsin inhibitor (Sigma). The cells were washed and suspended in MB buffer at the appropriate density for binding assays. In addition, two aliquots of trypsinized cells were placed in TYM-serum medium for an additional $2 \mathrm{~h}$ with and without $10 \mathrm{nM}$ cycloheximide, a protein synthesis inhibitor (Alderete \& Garza, 1985). Parasites were monitored throughout to ensure that experimental conditions did not affect viability and motility.

Immunofluorescence. FN- and LM-coated cover-slips were placed in individual wells of a 24-well plate with $200 \mu \mathrm{l}$ PBS containing $5 \mu \mathrm{l}$ of either rabbit anti-FN or anti-LM serum, respectively. Normal rabbit serum (NRS) served as a negative control on cover-slips handled similarly. Cover-slips were incubated on a shaker for $30 \mathrm{~min}$ at $4{ }^{\circ} \mathrm{C}$ before being washed in cold PBS. Then, $250 \mu \mathrm{l}$ cold PBS containing $5 \mu$ l goat antirabbit antibody conjugated with fluorescein isothiocyanate (Sigma) was added. Cover-slips were incubated in the dark for 30 min at $4{ }^{\circ} \mathrm{C}$ followed by washing with cold PBS and placing onto glass slides for observation by epifluorescence.

Antibody pretreatment of trichomonads. IgG antibody was purified from prebleed NRS and anti-adhesin sera, reported and used previously by us (Arroyo et al., 1992). Parasites were suspended in $\mathrm{MB}$ buffer at $2 \times 10^{6} \mathrm{ml}^{-1}$ in the presence of $400 \mu \mathrm{M}$ TLCK to inhibit cysteine proteinases known to degrade immunoglobulins (Provenzano \& Alderete, 1995). One microgram, $5 \mu \mathrm{g}$ and $50 \mu \mathrm{g}$ of each of the four antiadhesin IgGs were pooled prior to mixing with live trichomonads. As a control, $50 \mu \mathrm{g}$ NRS IgG was used. Trichomonads were pretreated with $\operatorname{IgG}$ for $10 \mathrm{~min}$ at $37^{\circ} \mathrm{C}$ prior to addition of the parasite-antibody mixture to wells containing coated cover-slips.

Electrophoresis and immunoblotting. Total protein preparations of parasites, grown either in high- or low-iron TYM-serum medium, were prepared as described before (Lehker \& Alderete, 1992). Briefly, $2 \times 10^{7}$ cells were washed and suspended in $1 \mathrm{ml}$ cold PBS-TCA $(10 \%, \mathrm{v} / \mathrm{v})$, and total proteins were precipitated overnight at $4{ }^{\circ} \mathrm{C}$. The protein pellet was collected by microcentrifugation at $4{ }^{\circ} \mathrm{C}$ and washed three times with cold PBS. Proteins were dissolved by suspension and boiling in electrophoresis dissolving buffer (Laemmli, 1970). Standard SDS-PAGE was performed using $4 \%$ stacking and $7 \%$ separating acrylamide gels (Laemmli, 1970). The proteins and molecular size markers (Amersham) were visualized by staining of gels with Coomassie brilliant blue R (Laemmli, 1970).

To visualize FN, proteins from supernatants or cell pellets were blotted onto nitrocellulose after SDS-PAGE using a standard protocol (Towbin et al., 1979; Lehker \& Alderete, 1992). Membranes were incubated in TNT (10 mM Tris/ $\mathrm{HCl}$, $\mathrm{pH} 8 \cdot 0 ; 150 \mathrm{mM} \mathrm{NaCl} ; 0.05 \%$ Tween 20 ) buffer with $5 \%$ non-fat milk as a blocking agent. Nitrocellulose blots were then incubated overnight at $4{ }^{\circ} \mathrm{C}$ in goat anti-FN $\operatorname{IgG}(1: 400)$, followed by washing in TNT buffer, and incubated for $1 \mathrm{~h}$ at room temperature in rabbit anti-goat secondary antibody conjugated to alkaline phosphatase $(1: 4000)$ in TNT buffer with $3 \%$ milk. Blots were finally washed three times in TNT for development (Sambrook et al., 1989).

Statistical analysis. Unless otherwise stated, each experiment was performed at least three times, and each representative experiment included quadruplicate samples. Except where noted differently, percentage binding of parasites to substrate on cover-slips is c.p.m. bound divided by total c.p.m added per well and multiplied by 100 . As all the data have a normal distribution, the Student's $t$ test was performed where indicated.

\section{RESULTS}

\section{Optimization of parasite binding to FN and LM}

Because FN and LM immobilized on cover-slips has been used previously by us to study their interaction with microbial pathogens (Peterson et al., 1983; Thomas et al., 1985), we first determined the optimal amount of FN and LM immobilized on cover-slips for association with $10^{6}$ radiolabelled trichomonads. Amounts ranging from 0.25 to $20 \mu \mathrm{g}$ were coated onto the cover-slips. Maximal numbers of organisms binding to both FN and LM surfaces was within the $1 \mu \mathrm{g}$ range. This amount of protein on cover-slips was then employed for subsequent experiments. Two million trichomonads $\mathrm{ml}^{-1}$ gave maximal numbers bound for both FN and LM coverslips (Fig. 1a). Fig. 1(b) shows that using $10^{6}$ trichomonads in the assay gave the highest numbers of organisms bound on FN by $30 \mathrm{~min}$, and levels were maintained up to $60 \mathrm{~min}$. In contrast, Fig. 1(c) illustrates that highest binding levels to LM occurred by $15 \mathrm{~min}$ and remained maximal for $30 \mathrm{~min}$. A decrease in numbers of organisms was seen during extended incubations with both substrates. Addition to the interaction buffer of TLCK, a cysteine proteinase inhibitor, resulted in higher numbers of organisms bound to $\mathrm{FN}$, but not to LM. These preliminary results suggest that the numerous trichomonad proteinases synthesized (Neale \& Alderete, 1990; Provenzano \& Alderete, 1995) and released (Lockwood et al., 1988) may adversely affect maximal levels of parasites associating with the immobilized FN.

\section{Growth in medium or extended incubation in binding buffer affects the levels of $T$. vaginalis organisms binding to $\mathrm{FN}$-coated cover-slips}

Extended incubations resulting in loss of binding to immobilized substrates as seen above in Fig. 1(b, c) could be due to alteration of the parasite surface and/or degradation of the FN on cover-slips. To test for these possibilities, mid-exponential phase organisms were harvested and divided into three groups. Group one parasites were suspended in $\mathrm{MB}$ buffer and interacted with the FN cover-slips for $30 \mathrm{~min}$ and $180 \mathrm{~min}$ at $37^{\circ} \mathrm{C}$. Groups two and three were trichomonads suspended in MB buffer or TYM growth medium, respectively, at the 

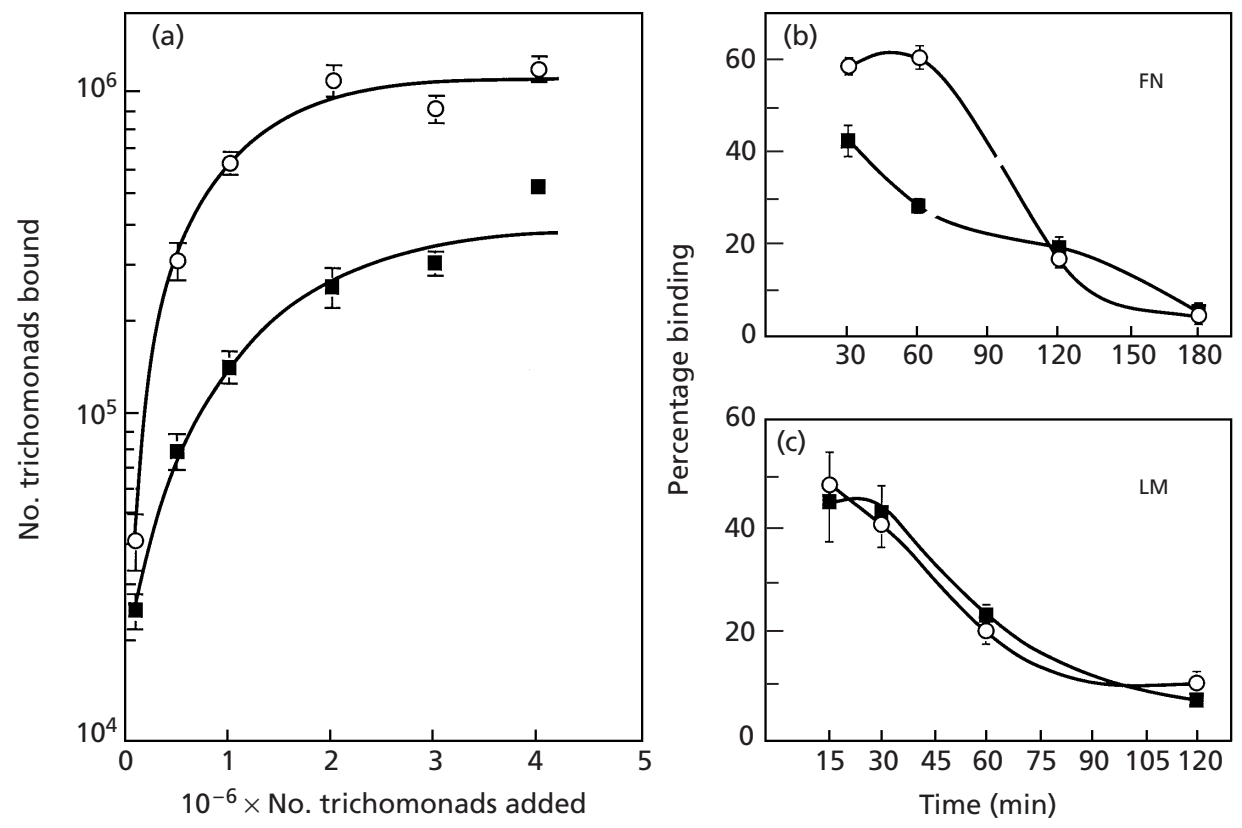

Fig. 1. Representative experiments showing optimization of the in vitro binding assay. (a) Increasing densities of parasites, suspended in MB buffer containing $400 \mu \mathrm{M}$ TLCK, were added to each well with coated cover-slips. Cells were incubated for $30 \mathrm{~min}$ at $37^{\circ} \mathrm{C}$ as described in Methods. O, FN; $\mathbf{\square}, \mathrm{LM}$. (b, c) Trichomonads $\left(10^{6}\right)$ were incubated for up to $3 \mathrm{~h}$ at $37^{\circ} \mathrm{C}$ on either FN- or LM-coated cover-slips with or without a cysteine proteinase inhibitor $(400 \mu \mathrm{M})$ added to the buffer. $O$, +TLCK; $\mathbf{\square},-$ TLCK.

same density and incubated for $180 \mathrm{~min}$ at $37^{\circ} \mathrm{C}$ prior to addition to the FN-coated cover-slips. Group one organisms were harvested after the 180 min incubation, washed, and placed onto newly coated cover-slips. The cover-slips from the $180 \mathrm{~min}$ group one parasites were also washed prior to addition of the group three freshly harvested, radiolabelled parasites. As presented in Fig. 2 and consistent with the above results, fresh $20 \mathrm{~h}$ midexponential phase parasites bound to newly coated cover-slips by $30 \mathrm{~min}$ (column 1) followed by decreased binding by $180 \mathrm{~min}$ (column 2). The $180 \mathrm{~min}$ organisms remained viable and motile but were unable to associate with newly coated FN cover-slips (column 3). Group two parasites placed in MB buffer alone also gave low levels of binding to FN cover-slips, as seen in column 3. These results suggest that extended incubation in the MB buffer leads to alteration of the parasite, resulting in an inability to attach to the FN-coated cover-slips. It is noteworthy that the 180 min parasites, although unable to bind to FN cover-slips (column 3), had associated FN, as detected by immunoblot analysis of total trichomonad proteins probed with goat anti-FN serum (data not shown). These data reinforced $30 \mathrm{~min}$ as the optimal binding period. Moreover, group three trichomonads attached at higher levels (column 4) compared to organisms directly from $20 \mathrm{~h}$ mid-exponential phase of growth (column 1). Binding levels were higher with new (column 4) versus used (column 5) cover-slips, suggesting strongly that $\mathrm{FN}$ is modified during extended incubation with live organisms. The results indicate that experiments evaluating optimal interactions between $T$. vaginalis organisms and ECM components require that mid-exponential phase organisms be placed in fresh medium prior to use in binding assays.

During our optimization of the binding assay and since addition of TLCK to the interaction buffer affected binding to FN only (Fig. 1b, c), we tested whether trichomonads degraded FN present on the cover-slips. To this end, cover-slips coated with $30 \mu \mathrm{g}$ FN were incubated with parasites as described in Methods. As shown in Fig. 3(a), supernatants after interaction of cover-slips with trichomonads contained soluble FN that was degraded in a time-dependent manner. We also examined for FN degradation under the optimal experimental conditions employed for measuring binding to this substrate (Methods). As seen in Fig. 3(b), supernatants contained degraded FN released from the coated cover-slips, and this degradation was inhibited by TLCK. Analysis by immunoblot of total proteins from washed parasites recovered from supernatants detected FN bound to trichomonads (data not shown), possibly leading to the decrease in numbers bound to cover-slips as shown in Fig. 2. These results show the ability of $T$. vaginalis organisms to actively release and degrade immobilized FN substrate. Although this aspect of parasite-substrate interactions was not examined for LM, it is likely that similar events also occur, as we have shown previously that trichomonads degrade BM (Provenzano \& Alderete, 1995), of which LM is a component. Collectively, the data suggest that a combination of modifications occurring on trichomonads and target substrate affects binding levels of parasites at extended periods. 


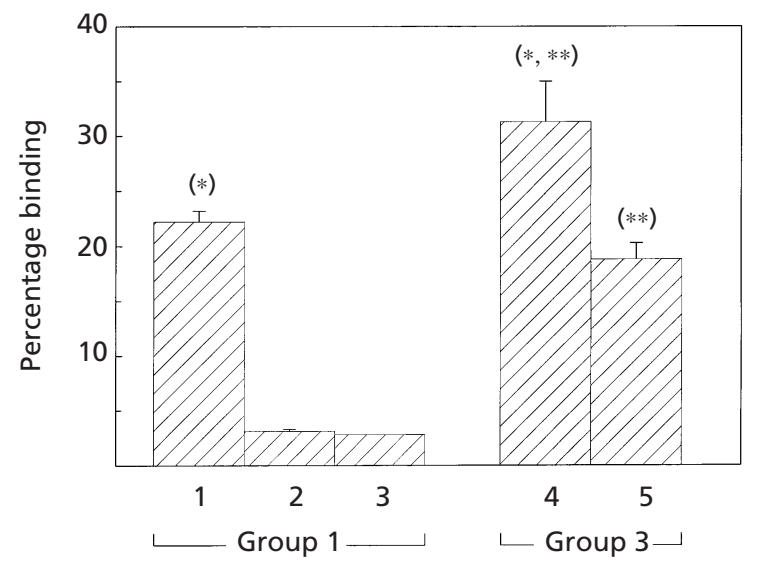

Fig. 2. Representative experiment showing that growth and extended incubations influence numbers of organisms bound to FN cover-slips. For this experiment, radiolabelled trichomonads were derived directly from the $20 \mathrm{~h}$ mid-exponential phase of growth (group one). Columns 1 and 2 show the levels of parasite $\left(10^{6}\right)$ binding at 30 and $180 \mathrm{~min}$ incubation, respectively. Parasites at $180 \mathrm{~min}$ incubation (column 2) were then washed in MB buffer and placed with new protein-coated cover-slips (column 3). Note the absence of any increased association with these cover-slips. Trichomonads from the midexponential phase of growth were placed in MB buffer for $3 \mathrm{~h}$ prior to incubation with FN cover-slips (group two). These group two parasites gave levels of binding equal to those seen in column 3. Organisms at the mid-exponential phase of growth were incubated in fresh TYM medium for an additional $3 \mathrm{~h}$ (group three). Parasites were then washed and added to newly coated (column 4) versus used (column 5) cover-slips derived from prior incubation with trichomonads for $3 \mathrm{~h}$ (column 2). The Student's $t$ test was performed when comparing column 1 versus column 4 (single asterisk) and column 4 versus column 5 (double asterisk). Both were found to be significantly different ( $P<0.05$, for both).

\section{Trichomonad surface sites mediate binding to FN- and LM-coated cover-slips}

We next attempted to define the nature of the trichomonad surface structures involved in the interaction with FN and LM. As shown in Fig. 4(a), $1 \mathrm{mM}$ periodate treatment of trichomonads under conditions that do not adversely affect motility and viability (Alderete \& Garza, 1985) resulted in a $55 \%$ decrease in binding to LM but had no effect on parasite association with FN, suggesting that carbohydrates on the organisms were involved in LM binding. We further performed binding experiments in the presence of $250 \mathrm{mM}$ of various mono- and disaccharides (Alderete \& Garza, 1985), and no inhibition of parasite binding to LM was observed, reinforcing that complex carbohydrate structures might be involved.

As seen in Fig. 4(b), trypsinization of live parasites resulted in $85 \%$ and $70 \%$ decreased binding of organisms to FN and LM, respectively. Interestingly, placement of treated parasites in medium for $2 \mathrm{~h}$ resulted in full regeneration of binding to $\mathrm{FN}$ but only partial restoration of association with LM. Finally, incubation of trypsinized parasites in growth medium in the (a)

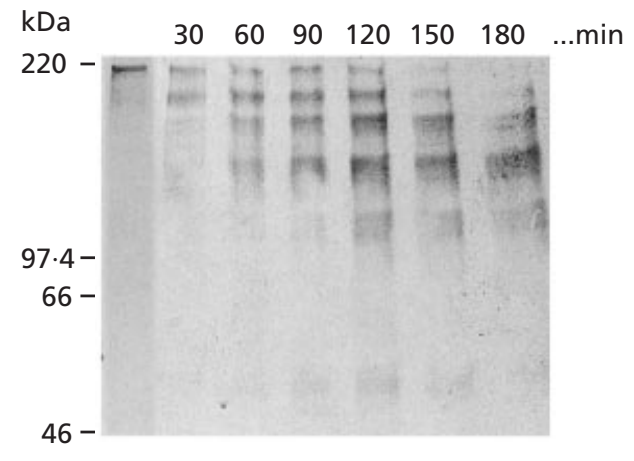

(b)

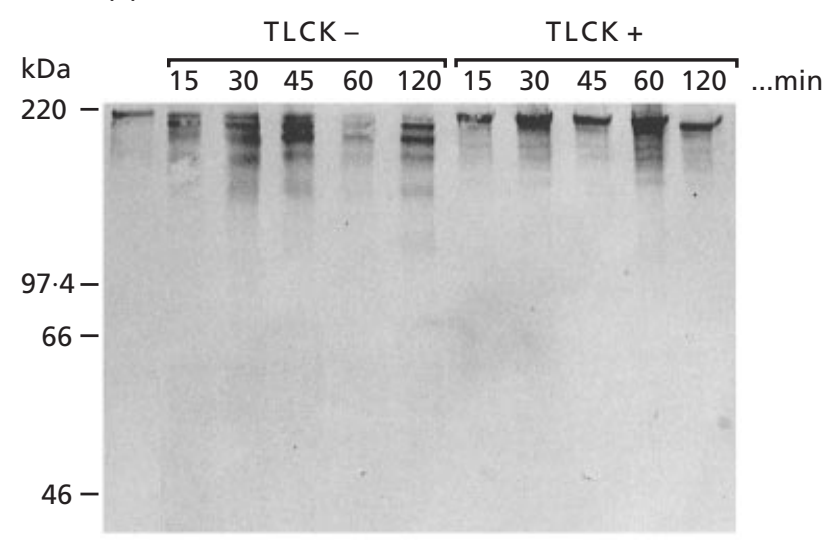

Fig. 3. Representative experiments showing degradation of immobilized FN by trichomonad cysteine proteinases. (a) Immunoblot detection of $\mathrm{FN}$ and $\mathrm{FN}$ fragments showing degradation of $30 \mu \mathrm{g}$ immobilized $\mathrm{FN}$ recovered from supernatant after incubation with trichomonads in TYM alone, as described in Methods. (b) Immunoblot detection of FN $(10 \mu \mathrm{g})$ released from cover-slips by $10^{6}$ parasites in the presence or absence of $400 \mu \mathrm{M}$ TLCK at $37^{\circ} \mathrm{C}$ for $3 \mathrm{~h}$.

presence of cycloheximide, a protein synthesis inhibitor, completely prevented the regeneration of binding to FN (data not shown), confirming the requirement for synthesis and surface placement of proteins on the $T$. vaginalis surface. These data strongly suggest that recognition and binding of $T$. vaginalis to $\mathrm{FN}$ and $\mathrm{LM}$ involve different molecules and mechanisms.

\section{T. vaginalis interaction with $\mathrm{FN}$ and $\mathrm{LM}$ is distinct from cytoadherence}

Because synthesis of adhesins and levels of cytoadherence are up-regulated by iron (Arroyo et al., 1993; Lehker et al., 1991), we further compared levels of binding of high- versus low-iron-grown parasites onto FN- or LM-coated cover-slips. As a control, the iron status of trichomonads was confirmed by electrophoretic analysis of differentially expressed proteins (Peterson \& Alderete, 1984b; Lehker \& Alderete, 1992). Binding to FN or LM was unaffected by the iron status of the organism (data not shown). Not unexpectedly, 


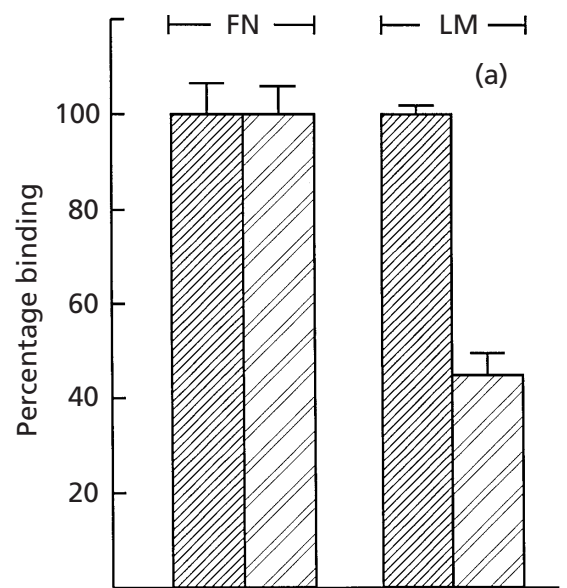

$1 \mathrm{mM}$ periodate... - $\quad+$

Trypsin...

Regeneration time

$(\min ) \ldots \quad 0 \quad 0$

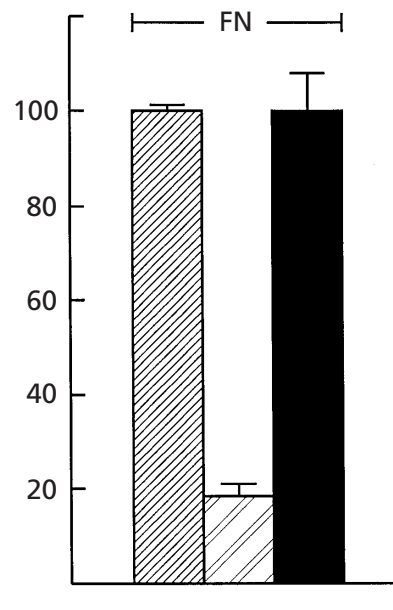

$-$

$-$

$0 \quad 0 \quad 120$ $\longmapsto \mathrm{LM} \longrightarrow$

(b)

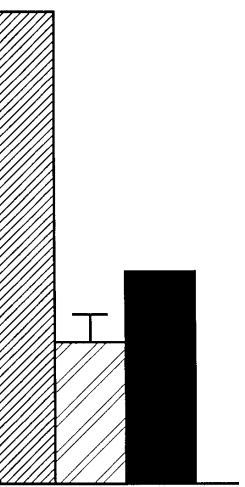

Fig. 4. Representative experiments showing that treatment of live parasites affects recognition and binding to FN- and LM-coated cover-slips. (a) Trichomonads $\left(2 \times 10^{7}\right)$ were treated with $1 \mathrm{mM}$ periodate as described in Methods prior to measuring numbers of organisms bound to FN- and LM-coated cover-slips after 30 min at $37^{\circ} \mathrm{C}$. (b) Live organisms were trypsinized and tested for binding to FN and LM. In this experiment and for optimal associations, parasites were harvested by centrifugation at mid-exponential phase, resuspended in fresh TYM-serum medium, and incubated at $37{ }^{\circ} \mathrm{C}$ for $2 \mathrm{~h}$. Trichomonads were then washed in MB buffer and incubated with $30 \mathrm{mg}$ trypsin for $30 \mathrm{~min}$ at $37^{\circ} \mathrm{C}$. The reaction was stopped by addition of equal amounts of trypsin inhibitor, and the organisms were prepared for binding. An aliquot of trypsinized trichomonads was also placed in growth medium for $2 \mathrm{~h}$ at $37^{\circ} \mathrm{C}$ and monitored for regeneration of binding to FN and LM on cover-slips as described in Methods. All untreated controls were handled identically and were represented as $100 \%$ organisms bound. Percentage binding of treated parasites represents numbers bound relative to untreated controls.

incubation of parasites with a mixture of antibodies to the T. vaginalis adhesins (Arroyo et al., 1992, 1995) had no effect on levels of organisms bound to FN-coated cover-slips. These results strongly indicate that the mode of T. vaginalis association with ECM proteins is distinct from cytoadherence.

\section{All $T$. vaginalis isolates tested interact with the immobilized substrates}

Finally, we felt it important to verify that other fresh clinical isolates of $T$. vaginalis bound comparably to $\mathrm{FN}$ and LM on cover-slips. Fig. 5 illustrates the results of several binding assays for isolate T016 and four additional trichomonal isolates. Data represent the mean of four separate experiments, and although binding for each isolate between each of the four experiments varied, statistical analysis shows that levels of binding to either FN or LM were not significantly different between isolates (Student's $t$ test, $P>0 \cdot 05, n=4$ ).

\section{DISCUSSION}

The non-self-limiting nature of mucosal infection by $T$. vaginalis may be the result of parasite infiltration into the ECM and BM space. The combination of parasitemediated contact-dependent and independent cytotoxicity (Alderete \& Pearlman, 1984; Krieger et al.,
1985) and exfoliation of the VECs suggests that despite the specific nature of trichomonal cytoadherence to VECs (Alderete \& Garza, 1985, 1988; Alderete et al., 1988; Lehker et al., 1991;Arroyo et al., 1992, 1995), alternative pathogenic mechanisms are required for long-term infection. Focal sites of erosion in the vaginal epithelium result from the presence of numerous tissuedegrading proteinases in vaginal secretions of women with trichomonosis (Alderete et al., 1991). It seems, therefore, possible that trichomonads are capable of reaching the ECM and $\mathrm{BM}$, and associate with FN and LM.

There are many reports in the literature on the specific nature of associations between microbial pathogens and ECM/BM membrane components (Westerlund \& Korhonen, 1993; Patti et al., 1994; Patti \& Hook, 1994). Candida albicans, an opportunistic yeast, attaches to ECM and BM molecules, and it is presumed that the interaction with immobilized FN and other ECM molecules enhances the establishment and maintenance of infection at sites outside its normal niche (Calderone \& Scheld, 1987; Klotz, 1994). Other mucosal pathogens, such as the streptococci, adhere to immobilized FN in a time- and dose-dependent manner (Kuusela et al., 1985; van der Flier et al., 1995). It may not be surprising, therefore, that $T$. vaginalis, a mucosal pathogen of the vaginal tract, utilizes components of the ECM and BM, 


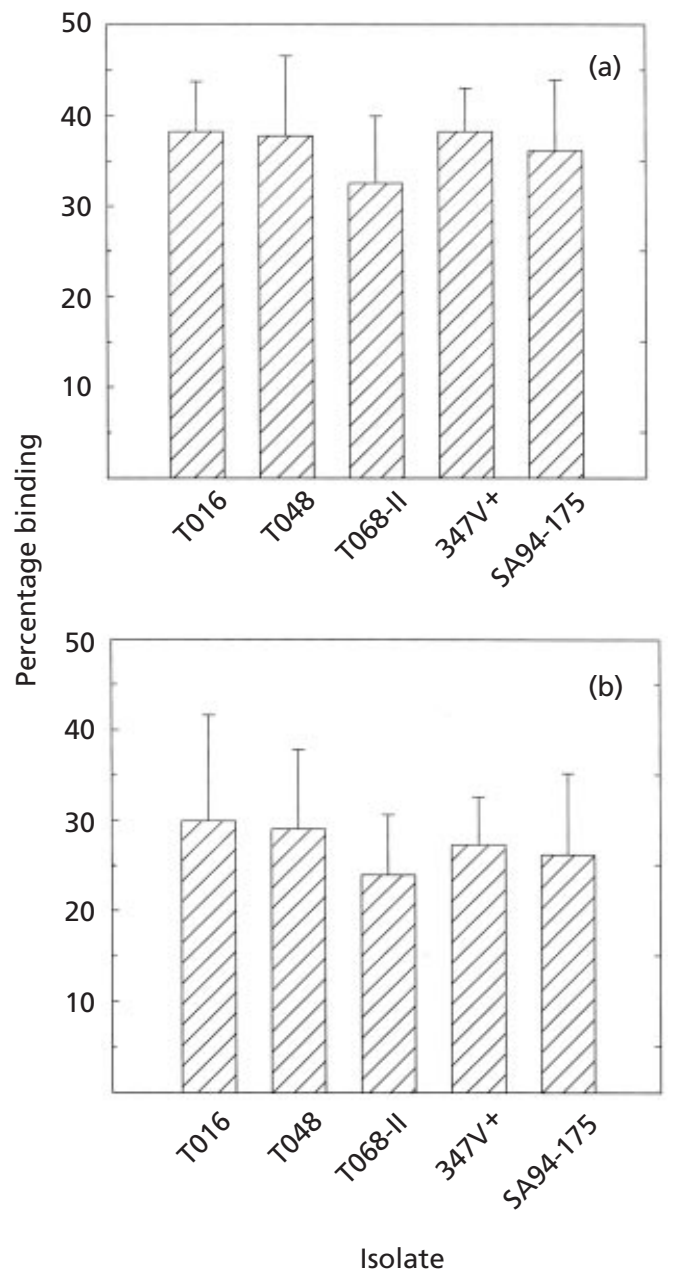

Fig. 5. Comparable binding of fresh clinical isolates of $T$. vaginalis to $\mathrm{FN}$ - and $\mathrm{LM}$-coated cover-slips. Binding assays to FN (a) and LM (b) were performed as described in Methods. The percentage binding represents the mean and standard deviation of numbers of organisms bound relative to numbers added. The Student's $t$ test shows that binding to either FN or LM was not significantly different between isolates $(P>0.05$, $n=4)$.

such as FN and LM, to establish colonization and cause persistent infection.

In this report, we demonstrate and characterize the nature of T. vaginalis binding to immobilized FN and LM. Trichomonad surface proteins appear to be involved in both FN and LM associations, as evidenced by the effect of protease treatment on live organisms (Fig. 4). This was supported by the ability to regenerate binding to FN upon placement of trypsinized cells back into culture. The absence of similar regeneration for the trichomonad association with LM may not be surprising, as the data indicate a role for surface proteins as well as complex carbohydrate structures on $T$. vaginalis in this interaction. It is important to note, however, that, while a protein moiety is involved in FN binding, the structure may still be in the form of a glycoprotein.
Molecular characterization of these structures awaits future experimentation.

The adhesin proteins mediating cytoadherence of $T$. vaginalis to VECs (Arroyo et al., 1992) were not involved in recognition and binding to FN and LM. Also, iron, an important modulator of expression of the adhesin genes (Lehker et al., 1991), played no role in parasite associations with either FN- or LM-coated cover-slips. These results suggest that variations in the concentration of lactoferrin, a known in vivo iron source for the parasite (Peterson \& Alderete, 1984b; Lehker \& Alderete, 1992), would not affect the ability of $T$. vaginalis to colonize host tissues. We have described the morphological transformation that occurs upon cytoadherence to VECs of T. vaginalis organisms (Arroyo et al., 1993). A change from the culture ellipsoid form to an amoeboid morphology was also seen on the immobilized FN and LM surfaces within the $30 \mathrm{~min}$ time point. These observations indicate the existence of signals similar to the ones observed during cytoadherence.

Under our experimental conditions, the binding assays did not allow all parasites to associate with the proteincoated cover-slips. Experiments were performed in which organisms that remained unbound after a $20 \mathrm{~min}$ incubation with immobilized FN were placed onto new FN-coated surfaces. In this manner, all trichomonads were found to attach to FN. These data suggest that the observed variations (Fig. 5) are probably due to the constraints within the assay system. It would also appear that trichomonads are capable of simultaneously adhering to VECs and attaching to ECM and BM regardless of the iron status at the site of infection.

We show that immobilized FN can be degraded by the parasite cysteine proteinases (Fig. 3). These results are consistent with earlier reports showing the ability of trichomonad cysteine proteinases, produced in vivo (Alderete et al., 1991), to degrade FN and ECM components as determined by substrate gel analyses (Provenzano \& Alderete, 1995). Degradation of FN at the site of infection may be significant. Studies with mammalian cells have shown that particular FN fragments can elicit various responses, such as changes in morphology (Chen \& Culp, 1998), attachment or detachment of cells from surfaces (Saiki et al., 1991; Fukai et al., 1997), and even apoptosis (Fukai et al., 1998). It is conceivable that, during infection, parasite degradation of ECM components could lead to unforeseen aspects of cytopathology (Draper et al., 1995) and/or host cell and parasite responses.

These data further highlight the complexity of this host-parasite relationship. These studies will ultimately help in understanding the persistence of parasites in an environment that undergoes dramatic changes over the course of the menstrual cycle. Furthermore, this report emphasizes the need to continue the characterization of the mechanisms and molecules involved in the $T$. vaginalis interaction with host cells and tissue components, including FN and LM, to fully clarify the nonself-limiting nature of infection. 


\section{ACKNOWLEDGEMENTS}

This study was supported by Public Health Service grants AI43940 and AI-39803 from the National Institute of Allergy and Infectious Diseases of the National Institutes of Health. M.-L.C. was supported in part by NIH Training Grant T32AI-07271. The excellent technical help of Andrew Alderete for his role in the purification of FN is acknowledged. We are grateful to Dr Thomas Prihoda for his help in the statistical analysis of the data. Special thanks to the members of the laboratory for their discussions throughout this study and for suggestions in preparing this manuscript.

\section{REFERENCES}

Alderete, J. F. \& Garza, G. E. (1985). Specific nature of Trichomonas vaginalis parasitism of host cell surfaces. Infect Immun 50, 701-708.

Alderete, J. F. \& Garza, G. E. (1988). Identification and properties of Trichomonas vaginalis proteins involved in cytoadherence. Infect Immun 56, 28-33.

Alderete, J. F. \& Pearlman, E. (1984). Pathogenic Trichomonas vaginalis cytotoxicity to cell culture monolayers. Br J Vener Dis 60, 99-105.

Alderete, J. F., Demeš, P., Gombošova, A., Valent, M., Fabušová, M., Janošká, A., Štefanovic, J. \& Arroyo, R. (1988). Specific parasitism of purified vaginal epithelial cells by Trichomonas vaginalis. Infect Immun 56, 2558-2562.

Alderete, J. F., Newton, E., Dennis, C. \& Neale, K. A. (1991). The vagina of women infected with Trichomonas vaginalis has numerous proteinases and antibody to trichomonad proteinases. Genitourin Med 674, 469-474.

Arroyo, R. \& Alderete, J. F. (1989). Trichomonas vaginalis surface proteinase activity is necessary for parasite adherence to epithelial cells. Infect Immun 57, 2991-2997.

Arroyo, R., Engbring, J. A. \& Alderete, J. F. (1992). Molecular basis of host epithelial cell recognition by Trichomonas vaginalis. Mol Microbiol 6, 853-862.

Arroyo, R., Gonzalez-Robles, A., Martinez-Palomo, A. \& Alderete, J. F. (1993). Signaling of Trichomonas vaginalis for amoeboid transformation and adhesin synthesis follows cytoadherence. Mol Microbiol 7, 299-309.

Arroyo, R., Engbring, J. A., Nguyen, J., Musatovova, O., Lopez, O., Lauriano, C. \& Alderete, J. F. (1995). Characterization of cDNAs encoding proteins involved in Trichomonas vaginalis cytoadherence. Arch Med Res 26, 361-369.

Benchimol, M., Batista, C. \& de Souza, W. (1990). Fibronectin- and laminin-mediated endocytic activity in the parasitic protozoa Trichomonas vaginalis and Tritrichomonas foetus. J Submicrosc Cytol Pathol 22, 39-45.

Calderone, R. A. \& Scheld, W. M. (1987). Role of fibronectin in the pathogenesis of candidal infections. Rev Infect Dis 9 (suppl. 4), S400-403.

Casta e Silva Filho, F., de Souza, W. \& Lopes, J. D. (1988). Presence of laminin-binding proteins in trichomonads and their role in adhesion. Proc Natl Acad Sci USA 85, 8042-8046.

Chen, W. \& Culp, L. A. (1998). Adhesion of fibronectin's EDb domain induces tyrosine phosphorylation of focal adhesion proteins in Balb/c 3T3 cells. Clin Exp Metastasis 16, 30-42.

Cotch, M. F., Pastorek, J. G., II, Nugent, R. P., Yerg, D. E., Martin, D. H. \& Eschenbach, D. A. (1991). Demographic and behavioral predictors of Trichomonas vaginalis infection among pregnant women. Obstet Gynecol 78, 1087-1092.
Diamond, L. S. (1957). The establishment of various Trichomonas of animals and man in axenic cultures. J Parasitol 43, 488-490.

Draper, D., McGregor, J., Hall, J., Jones, W., Beutz, M., Heine, R. P. \& Porreco, R. (1995). Elevated protease activities in human amnion and chorion correlate with preterm premature rupture of membranes. Am J Obstet Gynecol 173, 1506-1512.

van der Flier, M., Chhun, N., Wizemann, T. M., Min, J., McCarthy, J. B. \& Tuomanen, E. I. (1995). Adherence of Streptococcus pneumoniae to immobilized fibronectin. Infect Immun 63, 4317-4322.

Fukai, F., Hasebe, S., Ueki, M., Mutoh, M., Ohgi, C., Takahashi, H., Takeda, K. \& Katayama, T. (1997). Identification of the antiadhesive site buried within the heparin-binding domain of fibronectin. J Biochem 121, 189-192.

Fukai, F., Mashimo, M., Akiyama, K., Goto, T., Tanuma, S. \& Katayama, T. (1998). Modulation of apoptotic cell death by extracellular matrix proteins and fibronectin-derived antiadhesive peptides. Exp Cell Res 242, 92-99.

Hardy, P. H., Hardy, J. B., Nell, E. E., Graham, D. A., Spence, M. R. \& Rosenbaum, R. C. (1984). Prevalence of six sexually transmitted disease agents among pregnant inner-city adolescents and pregnancy outcome. Lancet ii, 333-337.

Klotz, S. A. (1994). Plasma and extracellular matrix proteins mediate in the fate of Candida albicans in the human host. Med Hypotheses 42, 328-334.

Krieger, J. N., Ravdin, J. I. \& Rein, M. F. (1985). Contact-dependent cytopathogenic mechanisms of Trichomonas vaginalis. Infect Immun 50, 778-786.

Krieger, J. N., Wolner-Hanssen, P., Stevens, C. \& Holmes, K. K. (1990). Characteristics of Trichomonas vaginalis isolates from women with and without colpitis macularis. J Infect Dis 161, 307-311.

Kuusela, P., Vartio, T., Vuento, M. \& Myrhe, E. B. (1985). Attachment of staphylococci and streptococci on fibronectin, fibronectin fragments, and fibrinogen bound to solid phase. Infect Immun 50, 77-81.

Laemmli, U. K. (1970). Cleavage of structural proteins during the assembly of the head of bacteriophage T4. Nature 277, 680-685.

Laga, M. A., Manoka, A., Kivuvu, M. \& 10 other authors (1993). Non-ulcerative sexually transmitted diseases as risk factors for HIV-1 transmission in women: results from a cohort study. AIDS 7, 95-102.

Lehker, M. W. \& Alderete, J. F. (1992). Iron regulates growth of Trichomonas vaginalis and the expression of immunogenic trichomonad proteins. Mol Microbiol 6, 123-132.

Lehker, M. W., Arroyo, R. \& Alderete, J. F. (1991). The regulation by iron of the synthesis of adhesins and cytoadherence levels in the protozoan Trichomonas vaginalis. J Exp Med 174, 311-318.

Lockwood, B. C., North, M. J. \& Coombs, G. H. (1988). The release of hydrolases from Trichomonas vaginalis and Tritrichomonas foetus. Mol Biochem Parasitol 30, 135-142.

Minkoff, H., Grunebaum, A. N., Schwarz, R. H., Feldman, J., Cummings, M., Crobleholme, W., Clark, L., Pringle, G. \& McCormack, W. M. (1984). Risk factors for prematurity and premature rupture of membranes: a prospective study of the vaginal flora in pregnancy. Am J Obstet Gynecol 150, 965-972.

Neale, K. A. \& Alderete, J. F. (1990). Analysis of the proteinases of representative Trichomonas vaginalis isolates. Infect Immun 58, 157-162.

Patti, J. M. \& Hook, M. (1994). Microbial adhesins recognizing extracellular matrix macromolecules. Curr Opin Cell Biol 6, $752-758$. 
Patti, J. M., Allen, B. L., McGavin, M. J. \& Hook, M. (1994). MSCRAMM-mediated adherence of microorganisms to host tissues. Annu Rev Microbiol 48, 585-617.

Peterson, K. M. \& Alderete, J. F. (1982). Host plasma proteins on the surface of pathogenic Trichomonas vaginalis. Infect Immun 37, 755-762.

Peterson, K. M. \& Alderete, J. F. (1984a). Selective acquisition of plasma proteins by Trichomonas vaginalis and human lipoproteins as growth requirements for this species. Mol Biochem Parasitol 12, 37-48.

Peterson, K. M. \& Alderete, J. F. (1984b). Iron uptake and increased intracellular enzyme activity follow host lactoferrin binding by Trichomonas vaginalis receptors. J Exp Med 160, 398-410.

Peterson, K. M., Baseman, J. B. \& Alderete, J. F. (1983). Treponema pallidum receptor binding proteins interact with fibronectin. J Exp Med 157, 1958-1970.

Provenzano, D. \& Alderete, J. F. (1995). Analysis of human immunoglobulin-degrading cysteine proteinases of Trichomonas vaginalis. Infect Immun 63, 3388-3395.

Provenzano, D., Koshnan, A. \& Alderete, J. F. (1997). Involvement of dsRNA virus in the protein composition and growth kinetics of host Trichomonas vaginalis. Arch Virol 142, 939-952.

Read, J. S. \& Klebanoff, M. A. (1993). Sexual intercourse during pregnancy and preterm delivery: effects of vaginal microorganisms. Am J Obstet Gynecol 129, 629-636.

Saiki, I., Makabe, T., Yoneda, J., Murata, J., Ishizaki, Y., Kimisuka, F., Kato, I. \& Azuma, I. (1991). Inhibitory effects of fibronectin and recombinant polypeptides on the adhesion of metastatic melanoma cells to laminin. Jpn J Cancer Res 82, 1112-1119.

Sambrook, J., Fritsch, E. F. \& Maniatis, T. (1989). Molecular Cloning: a Laboratory Manual, 2nd edn. Cold Spring Harbor, NY : Cold Spring Harbor Laboratory.

Soper, D. E., Bump, R. C. \& Hurt, G. W. (1990). Bacterial vaginosis and trichomoniasis vaginitis are risk factors for cuff cellulitis after abdominal hysterectomy. Am J Obstet Gynecol 163, 1016-1023.

Thomas, D. D., Baseman, J. B. \& Alderete, J. F. (1985). Fibronectin mediates Treponema pallidum cytadherence through recognition of fibronectin cell-binding domain. J Exp Med 161, 514-525.

Towbin, H., Staehelin, T. \& Gordon, J. (1979). Electrophoretic transfer of proteins from polyacrylamide gels to nitrocellulose sheets: procedure and some applications. Proc Natl Acad Sci USA 76, 4350-4354.

Warton, A. \& Honigberg, B. M. (1980). Lectin analysis of surface saccharides in two Trichomonas vaginalis strains differing in pathogenicity. J Protozool 27, 410-419.

Warton, A. \& Honigberg, B. M. (1983). Analysis of surface saccharides in Trichomonas vaginalis strains with various pathogenicity levels by fluorescein-conjugated plant lectins. $Z$ Parasitenkd 69, 149-159.

Wasserheit, J. N. (1992). Interrelationship between human immunodeficiency virus infection and other sexually transmitted diseases. Sex Transm Dis 19, 61-77.

Westerlund, B. \& Korhonen, T. K. (1993). Bacterial proteins binding to the mammalian extracellular matrix. Mol Microbiol 9, 687-694.

Wolner-Hanssen, P., Krieger, J. N., Stevens, C. E., Kiviat, N. B., Koutsky, L., Crichlow, C., DeRouen, T., Hillier, S. \& Holmes, K. K. (1989). Clinical manifestations of vaginal trichomoniasis. JAMA ( $J$ Am Med Assoc) 261, 571-576.

World Health Organization (1995). An overview of selected curable sexually transmitted diseases. WHO Global Programme on AIDS Report.

Zhang, Z. \& Begg, C. B. (1994). Is Trichomonas vaginalis a cause of cervical neoplasma? Results from a combined analysis of 24 studies. Int J Epidemiol 23, 682-690.

Received 11 February 1999; revised 6 May 1999; accepted 4 June 1999. 